\title{
RESIDUAL EFFECTS OF PESTICIDES ON HUMAN HEALTH AS PERCEIVED BY FARMERS IN TEHSIL FAISALABAD SADAR, PUNJAB, PAKISTAN.
}

\author{
1. M.Phil Student \\ Institute of Agricultural Extension \\ and Rural Development \\ University of Agriculture Faisalabad, \\ Punjab, Pakistan \\ 2. PhD \\ Assistant Professor \\ Institute of Agricultural Extension \\ and Rural Development \\ University of Agriculture Faisalabad, \\ Punjab, Pakistan \\ 3. PhD Student \\ Institute of Agricultural Extension \\ and Rural Development \\ University of Agriculture Faisalabad, \\ Punjab, Pakistan \\ 4. PhD \\ Professor Institute of Agricultural \\ Extension and Rural Development \\ University of Agriculture Faisalabad, \\ Punjab, Pakistan. \\ 5. PhD \\ Associate Professor \\ Institute of Agricultural Extension \\ and Rural Development \\ University of Agriculture Faisalabad, \\ Punjab, Pakistan.
}

Correspondence Address:

Sohaib Usman

Institute of Agricultural Extension and

Rural Development

University of Agriculture Faisalabad,

Punjab, Pakistan.

sohaibusmancheema174@gmail.com

Article received on:

21/10/2019

Accepted for publication:

29/12/2019

\section{Aisha Rani ${ }^{1}$, Aqeela Saghir ${ }^{2}$, Sohaib Usman ${ }^{3}$, Khalid Mahmood Ch. ${ }^{4}$, Shoukat Ali ${ }^{5}$}

ABSTRACT... Objectives: The aim of this study is to check the farmer's perception regarding use of chemicals (pesticides, herbicides, fungicides, rodenticides) in vegetables and its effects on human health in peri urban areas of tehsil Faisalabad Saddar. Instead of using organic matter, there is highly preference of fertilizers, pesticides, fungicides, herbicides and rodenticides in order to achieve the high yield and green revolution. Study Design: Prospective, crosssectional, observational study. Setting: Institute of Agricultural Extension \& Rural Development, University of Agriculture Faisalabad. Period: September 2017 to August 2019. Material \& Methods: Sample size comprises 128 respondents. From two peri-urban union councils (4 villages, vegetables growing) were selected purposively. While 32 farmers were selected from each village. A pre-tested and well-structured interview schedule was developed for data collection. Result: The results indicated that various diseases were present among farmers due to use of chemicals and residual effects. The diseases were chest pain, damage of liver, diarrhea, dizziness, eye irritation, sleeplessness, dryness of throat, shortness of breath, swelling of skin, fever, hypertension, tiredness and stomach disturbance. Pearson correlation coefficient shows significant and positive relation between age of the respondents and diseases they had $\mathrm{P}<0.05$. More than half $56.3 \%$ of the respondents knew that ground water becomes contaminated by the use of chemicals. A vast majority $90.6 \%$ of the respondents used to avoid storing of pesticides, fungicides and weedicides. Results also indicated that diseases and adoption of precautionary measures were directly related with lack of awareness. Conclusion: There is dire need to start campaigns through media regarding awareness about harmful effects of residues on human health and organic farming should be preferred over chemicals.

Key words: Diseases, Farmers Awareness, Farmer's Health, Precautionary Measures, Residual Effects, Vegetables.

Article Citation: Rani A, Saghir A, Usman S, Ch. KM, Ali S. Residual effects of pesticides on human health as perceived by farmers in Tehsil Faisalabad Sadar, Punjab, Pakistan. Professional Med J 2020; 27(2):395-402.

DOI: $10.29309 / \mathrm{TPMJ} / 2020.27 .2 .4256$

\section{INTRODUCTION}

Residues in vegetables show that there is presence of chemicals in higher quantity where there is extreme risk of harm. After the application, pesticide residues represent the pesticides that persist in food $^{1}$, these residues are harmful. ${ }^{2}$ Food is contaminated by harmful chemicals and cause lots of diseases on human health. ${ }^{3}$ Due to catastrophic nature pesticides also have deleterious effects in pregnant woman, depend on chemical and phase of pregnancy, according to European Commission (2002) growth retardation of fetus could be possible in pregnant woman during organogenesis period (22-50 days since fertilization). Pesticides have toxic effects more on children than elders because children organs keep developing quickly and skin sensitivity. ${ }^{4}$ The children neural growth and the immune response is badly affected by polychlorinated biphenyls (PCBs) exposure because of nutrition infection. ${ }^{5}$ Overindulgent level of substances in food like insecticides cause neural and kidney harm, congenital disabilities, reproductive problem and can prove to be cancer-causing. "According to the US Centre for Disease Control and Prevention 11,000 food pollutants were anticipated in 2013". ${ }^{7}$ Gastro intestinal diseases caused by ingestion of filthy food with insecticides and hefty metals. ${ }^{8} \mathrm{We}$ are using artificial ways in fruits and vegetables ripening which is affecting the body cells and 
also becoming reason for osteoporosis. All these health hazards also transfer to the next generations. "A study examined the exposure of various food contaminants on children and concluded that all the children had cancer for DDE, dieldrin, arsenic, and dioxins". ${ }^{9}$

Nutrition contain dangerous substances have severe harmful results and lead to elongate wicked reverberation. The effect of contaminated food starts from minor gastric problems which goes on further and lead to complete health deterioration as a result fatality happens. ${ }^{10}$ Due to lack of knowledge in Pakistan, majority of farmers were unaware regarding health problems because of incongruous management of pesticides. Health of farmers is at high risk due to failure in accessibility of befitting preventive measures and tools. ${ }^{11}$ Though we know that vegetables are very important part of human diet but unfortunately vegetables are full of nitrates and hefty metals as well as other anions. ${ }^{12,13}$ Health problems like headache, nausea, cancer, endocrine disruption demolished aptitude, immune suppression, procreative anomalies and metabolic process has been linked with pesticides residues in food that enters through diet chain. ${ }^{14,15,16,17}$ Leafy vegetables such as fenugreek, spinach, corriander and mint have extreme quantity of nitrate. Cancer disease is connected with high intake of nitrate. ${ }^{18}$ Residues of pesticides were collected in vegetables samples form disparate places everywhere in Multan city and Islamabad Sunday markets, Pakistan. ${ }^{19} \mathrm{~A}$ person genetic makeup, sex, lifestyle, dizziness, weakness, cramp, diarrhea, sweating skin rash, irritation of eyes, vomiting, lungs problems and increased heart rate are affected by use of manmade organophosphate insecticide that is known as malathion. ${ }^{20}$

Residual effects of pesticides on human health.

"Nearby 3 billion $\mathrm{kg}$ of insecticides are practiced each year everywhere in the world, result as serious danger in contamination of food". ${ }^{21}$

\section{METHODOLOGY}

An observational study was organized in peri-urban areas of tehsil Faisalabad Sadder purposively from September 2017 to August 2019. Consecutive vegetable growers using pesticides (insecticide, fungicides, herbicides and rodenticides) were registered by agricultural extension department, Male farmers were taken in inclusion criteria. However, the vegetables consumers, street vendors or farmers that unwilling to participate in the research study were excluded. The sampling practice continued till recruitment of 128 prior calculated subjects. For the purpose of quantitative analysis, data was gathered through well-organized interview schedule containing two sections variables i.e. (A) demographic variables and (B) awareness level, usage of pesticides, health issues, disease, regarding the research objectives. A list of 400 vegetable grower were collected from agriculture extension office (peri-urban areas) of tehsil sadder Faisalabad. A sample size of 132 respondents was selected by using online sampling calculator with 95\% confidence level and confidence interval 7. Remaining 4 respondents were unable to provide the complete information as per requirement of the research study. The collected data was analyzed with the help of Statistical Package for Social Sciences (SPSS).

\section{RESULTS}

Data depicted in Table-I revealed that a vast majority (78.9) of the farmers had grown vegetables for both domestic and commercial purposes and more then half $(51.5 \%)$ of the farmers were illiterate.

In Figure-1 results revealed that $14.8 \%$ of respondents among the target population used to face eye irritation after application of chemicals.

Table-II indicates that awareness about the disturbance of soil fertility because of pesticide residues $\left(\right.$ mean $=3.09 \pm=1.239$ ) is at ranking $1^{\text {st }}$

Table-III also shows that $31-40$ years (16.4\%) respondents had heart disease.

Table- IV shows that majority of the farmers $(27.3 \%)$ were using over dose of chemicals had hepatitis disease. 
Table-V indicates that majority of primary passed respondents (36.7\%) had medium level awareness regarding awareness on effects of residues on human health.

\begin{tabular}{|c|c|c|c|}
\hline Variable & Category & $f$ & $\%$ \\
\hline \multirow{4}{*}{ Education } & Illiterate & 66 & 51.5 \\
\hline & Primary & 22 & 17.1 \\
\hline & Matriculation & 24 & 18.7 \\
\hline & Above Matriculation & 16 & 12.5 \\
\hline \multirow{3}{*}{ Type of Vegetables growers } & Leafy vegetables & 8 & 6.2 \\
\hline & Root vegetables & 21 & 16.4 \\
\hline & Both & 99 & 77.3 \\
\hline \multirow{3}{*}{ Purpose of growing vegetables } & Domestic & 11 & 8.5 \\
\hline & Commercial use & 16 & 12.5 \\
\hline & Both & 101 & 78.9 \\
\hline \multirow{2}{*}{$\begin{array}{l}\text { Use of over doze of insecticides, } \\
\text { fungicides, herbicides }\end{array}$} & Yes & 105 & 82.0 \\
\hline & No & 23 & 18.0 \\
\hline
\end{tabular}

Table-I. Distribution of respondents according to demographic characteristics

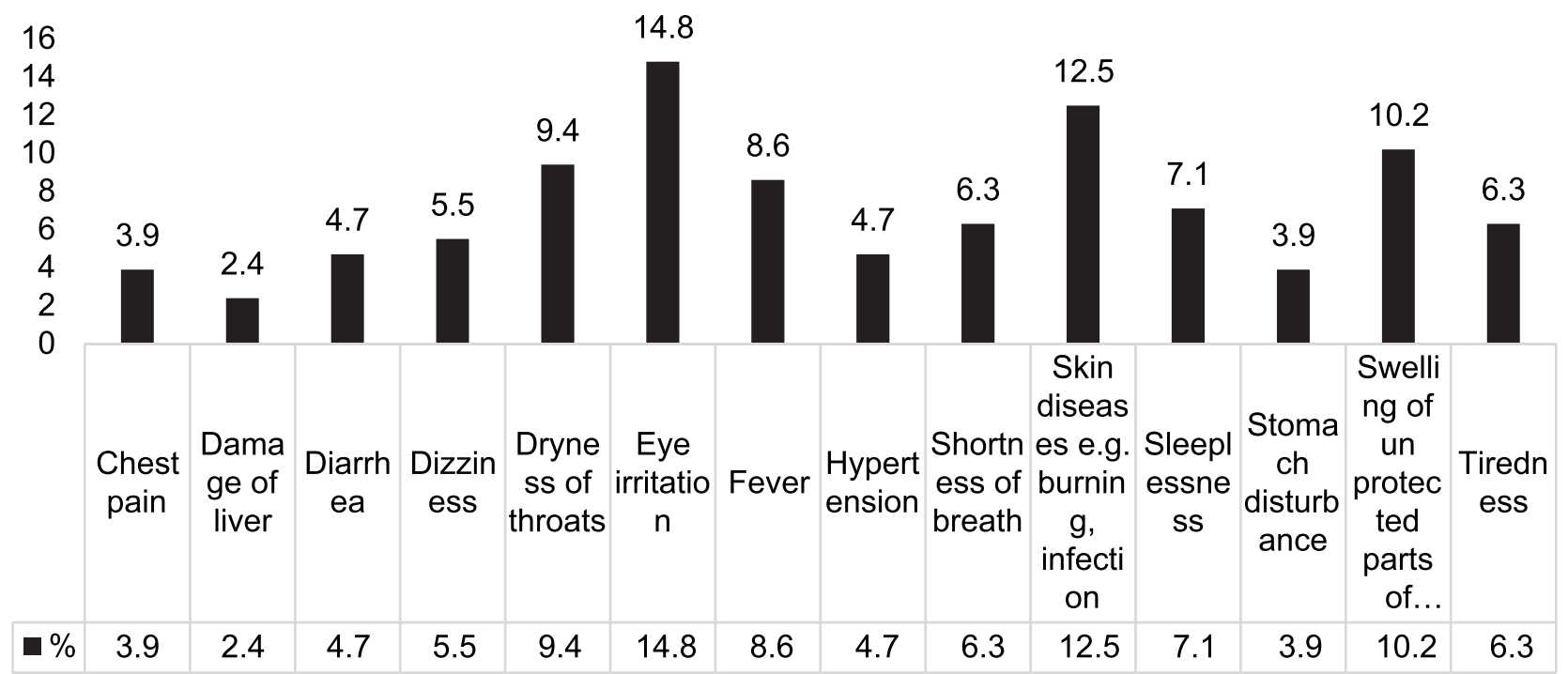

Figure-1. Graphical representation of respondents according to the symptoms after application of chemicals.

\begin{tabular}{|c|c|c|c|}
\hline Statement & Mean & S.D & Rank Order \\
\hline Soil fertility is disturb & 3.09 & 1.23 & 1 \\
\hline Beneficial insects of soil are effected & 2.66 & .70 & 2 \\
\hline After peeling or cleaning pesticides persisted & 2.60 & 1.42 & 3 \\
\hline Plants absorb filthy material from soil & 2.49 & .98 & 4 \\
\hline $\mathrm{PH}$ of soil disturb & 2.09 & 1.17 & 5 \\
\hline Proteinaceous effect of vegetables cease & 2.07 & 1.11 & 6 \\
\hline Effect on animal health & 2.01 & 1.27 & 7 \\
\hline Ground water contaminated & 1.78 & 1.06 & 8 \\
\hline
\end{tabular}




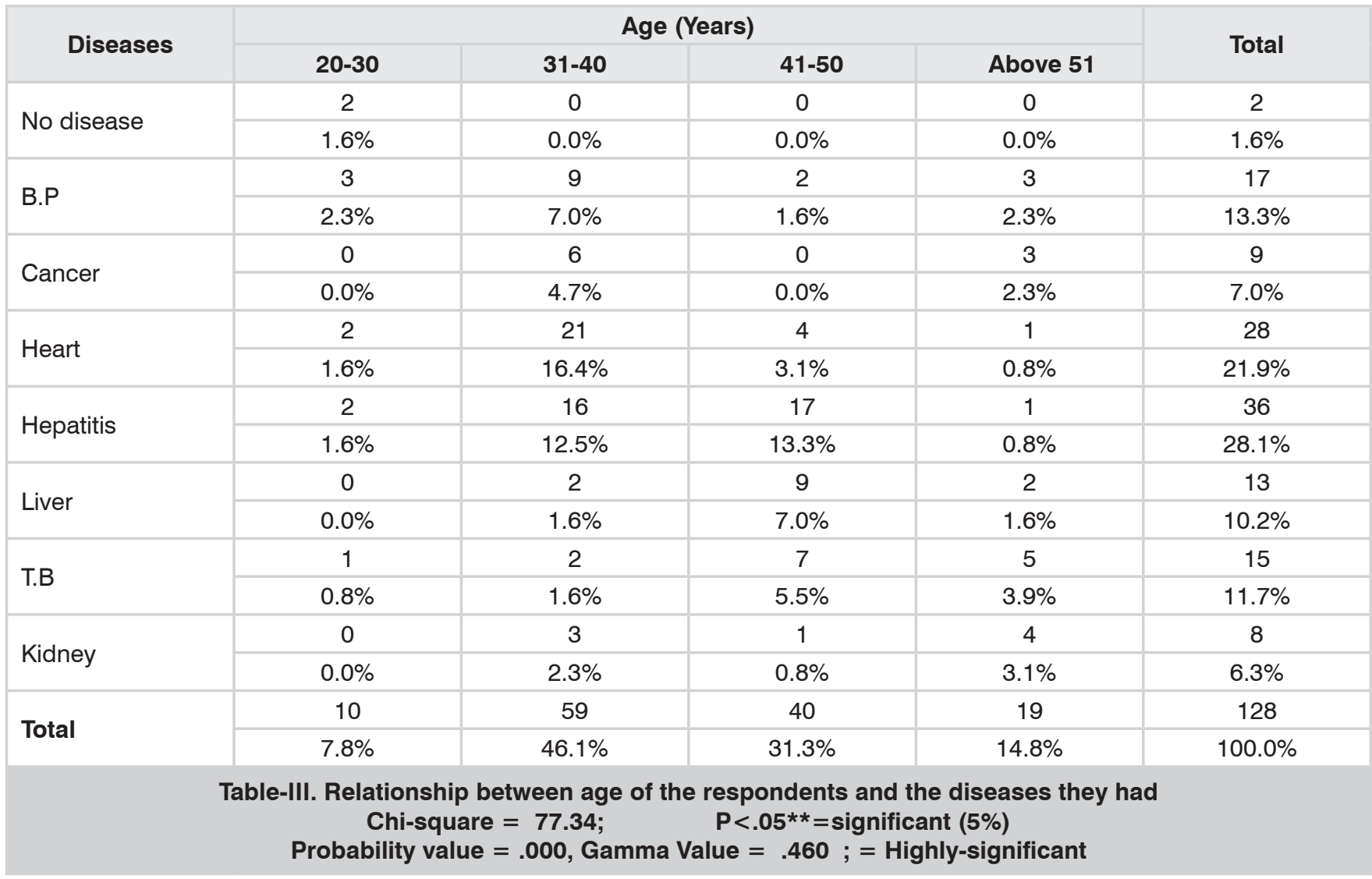

\begin{tabular}{|c|c|c|c|}
\hline \multirow{2}{*}{ Diseases } & \multicolumn{2}{|c|}{ Use of over dose of chemicals } & \multirow[t]{2}{*}{ Total } \\
\hline & Yes & No & \\
\hline \multirow{2}{*}{ No disease } & 2 & 0 & 2 \\
\hline & $1.6 \%$ & $0.0 \%$ & $1.6 \%$ \\
\hline \multirow{2}{*}{ B.P } & 13 & 3 & 16 \\
\hline & $10.2 \%$ & $2.3 \%$ & $12.5 \%$ \\
\hline \multirow{2}{*}{ Cancer } & 6 & 3 & 9 \\
\hline & $4.7 \%$ & $2.3 \%$ & $7.03 \%$ \\
\hline \multirow{2}{*}{ Heart } & 27 & 1 & 28 \\
\hline & $21.1 \%$ & $0.8 \%$ & $21.9 \%$ \\
\hline \multirow{2}{*}{ Hepatitis } & 35 & 1 & 36 \\
\hline & $27.3 \%$ & $0.8 \%$ & $28.1 \%$ \\
\hline \multirow{2}{*}{ Liver } & 11 & 4 & 15 \\
\hline & $8.6 \%$ & $3.1 \%$ & $11.7 \%$ \\
\hline \multirow{2}{*}{ T.B } & 7 & 9 & 16 \\
\hline & $5.5 \%$ & $7.0 \%$ & $12.5 \%$ \\
\hline \multirow{2}{*}{ Kidney } & 4 & 2 & 6 \\
\hline & $3.1 \%$ & $1.6 \%$ & $4.7 \%$ \\
\hline \multirow{2}{*}{ Total } & 105 & 23 & 128 \\
\hline & $82.0 \%$ & $18.0 \%$ & $100.0 \%$ \\
\hline \multicolumn{4}{|c|}{$\begin{array}{l}\text { Table-IV. Relationship between use of over dose of chemicals and diseases which the respondents had. } \\
\text { Chi-square = 29.098; } \quad \text { Probability value }=.000 \quad \text { Gamma Value }=.376=\text { Highly-significant }\end{array}$} \\
\hline
\end{tabular}




\begin{tabular}{|c|c|c|c|c|}
\hline \multirow[t]{2}{*}{ Education } & \multicolumn{3}{|c|}{ Awareness on effects of residues on health } & \multirow{2}{*}{ Total } \\
\hline & Low & Medium & High & \\
\hline Illiterate & 10 & 7 & 0 & 17 \\
\hline \multirow[t]{2}{*}{ Primary } & 6 & 47 & 3 & 56 \\
\hline & $4.7 \%$ & $36.7 \%$ & $2.3 \%$ & $43.8 \%$ \\
\hline Matriculation & $1.6 \%$ & $7.0 \%$ & $21.1 \%$ & $29.7 \%$ \\
\hline Above & 2 & 4 & 11 & 17 \\
\hline Matriculation & $1.6 \%$ & $3.1 \%$ & $8.6 \%$ & $13.3 \%$ \\
\hline Total & 20 & 67 & 41 & 128 \\
\hline
\end{tabular}

Table-V. Relationship between education and awareness of respondents regarding residual effects on health Chi-square $=85.293 ;$ Probability value $=.000 \quad$ Gamma Value $=.756=$ Highly-significant

\section{DISCUSSION}

Data depicted in Table-l. is portraying the purpose of vegetables growing by the farmers. Findings revealed that a vast majority (78.9) of the farmers had grown vegetables for both domestic and commercial purposes. They elaborated that vegetables that are grown at their farm not only fulfill their domestic needs but also fulfill their livelihood through commercial use. On the other hand, $12.5 \%$ of the farmers cultivated vegetables for commercial purpose. However, negligible percentage $(8.5 \%)$ of the farmers reported for domestic purpose of vegetables cultivation. Data depicted that more than half $(51.5 \%)$ of the farmers were illiterate. Farmers with matriculation were $18.7 \%$ and $17.1 \%$ of the farmers had up to primary level of education. Respondents with above matriculation were about $12.5 \%$ showed the similar results with some variation with those of present study. ${ }^{22}$

The response of the respondents regarding symptoms of chemicals after application is presented in Figure-1. Results revealed that 14.8\% of respondents among the target population used to face eye irritation after application of chemicals. $12.5 \%$ used to face skin diseases e.g. skin infection, burning. $10.2 \%$ used to face skin swelling diseases due to uncovering body parts while, 9.4\% used to feel dryness of throat after application and $8.6 \%$ used to feel fever. Due to chemical infection the sign of food borne disease range from minor gastro dynia to mortal cases of hepatic, renal, and neurological diseases. A whole of 1527 epidemic ailments were seen in the United States between 2009 and 2010, caused in 29,444 diseases cases and 23 expiries. ${ }^{23}$

The awareness level of respondents regarding residual effects in vegetables is presented in Table-Il. indicates that awareness about the disturbance of soil fertility because of pesticide residues (mean $=3.09 \pm=1.239$ ) is at ranking $1^{\text {st }}$, beneficial insects of soil are affected (mean $=2.66 \pm=.704)$ is at ranking $2^{\text {th }}$, after peeling or cleaning pesticides persisted (mean = $2.60 \pm=1.427$ ) and plants absorb filthy material from soil (mean $=2.49 \pm=.988$ ) is at ranking $3^{\text {th }}$ and $4^{\text {th }}, \mathrm{PH}$ of soil disturbed (mean $=2.09 \pm=1.171$ ) and proteinaceous effects of vegetables cease (mean $=2.07 \pm=1.117)$ is at ranking $5^{\text {th }}$ and $6^{\text {th }}$, effect on animal health (mean $=2.01 \pm=1.270$ ), and ground water also contaminated because of use of residues (mean $=1.78 \pm=1.064$ ) and were ranked $7^{\text {th }}$ to $8^{\text {th }}$, respectively. Mismanagement of insecticides initiated at local area, causes extreme damage to soil. ${ }^{24}$ Sustenance chain is formed by plants and plants effortlessly suck up filthy materials from the soil, by this action of plants not only fruits and vegetables become filthy as well as aquatic animals are also badly affected by this action. ${ }^{25}$

The link between age and the disease they were facing is presented in Table-III. Chi-square value indicates relationship between age and the effects 
of diseases they had. The gamma value shows a positive relationship between variables. Table-III. also shows that mostly 20-30 years respondents (2.3\%) had blood pressure, majority $31-40$ years (16.4\%) respondents had heart disease, 41$50(13.3 \%)$ respondents had hepatitis, while above 51 year (3.9\%)s of respondents had T.B. It is indicated that respondents having age 3140 Years were facing more diseases and they were large in numbers while 20-30 Years were facing less diseases. Adults, children and infants are being affected badly by eating pesticides residues in food. ${ }^{26}$

The link between use of overdose of chemicals and the disease they were facing is presented in Table- IV. The value of chi-square indicated that highly significant link between use of overdose of chemicals and diseases they had. The gamma value showed positive relationship between variables. It is indicated that respondents who were using over dose of chemicals were facing more diseases while those who were using lower dose of chemicals were facing less diseases. In developing countries farmers use pesticides on large scale without understanding of its harmful impact on human health and environment. ${ }^{27,28,29}$

Table-V. indicates the relationship between education and awareness level of respondents regarding residual effects on health. The value of chi-square indicated the highly significant link between education and awareness level. The gamma value showed positive relationship between variables. It means if the education level will increase then higher will be the level of awareness among respondents regarding residual effects. The high rate of illiteracy among farmers leads to their lack of knowledge about the side effects of pesticides and methods to alleviate these side effect ${ }^{1}$. It is highly recommended that training courses for farmers should be held to educate farmers on the side effects of pesticides, improve their knowledge. ${ }^{30}$

\section{CONCLUSION}

Illiterate and young people were not aware regarding the residual effects of pesticides on health. They had diseases like hepatitis, T.B, kidney, cancer, heart and blood pressure. After application of pesticides they have eye irritation, fever, skin burning and swelling because they do not take precautionary measures. Even so farmers prefer overdose of chemicals instead of required amount. Farmers in tehsil Faisalabad Saddar use chemicals because they are compelled to do so, there is no alternate method is available which is not only directly affecting the consumer's health but also farmers own health is deteriorating. There is need to create awareness campaigns in coordination with public and private health sectors.

\section{Copyright@ 29 Dec, 2019.}

\section{REFERENCES}

1. WHO. Pesticide residues in food. http://www.who.int/ feature/9a/87/en. Accessed on 28th September, 2016.

2. Botwe BO, Ntow WJ, Kelderman $P$, Drechsel $P$, Carboo D, Nartey VK, Gijzen HJ. Pesticide residues contamination of vegetables and their public health implications in Ghana. J. Environ. Issues Agric. Dev. Countries 2011; 3 (2): 1-18.

3. Faille C, Cunault C, Dubois T, Bénézech T. Hygienic design of food processing lines to mitigate the risk of bacterial food contamination with respect to environmental concerns. Innovative Food Science \& Emerging Technologies. 2018 Apr 1;46:65-73.

4. Colt JS, Davis S, Severson RK, Lynch CF, Cozen W, Camann $D$ et al. Residential insecticide use and risk of non-Hodgkin's Iymphoma. Cancer Epidemiology Biomarkers \& Prevention 2006; 15: 251-257.

5. Schantz S, Gardiner J, Gasior D, Caffrey R, Sweeney A, Humphrey $\mathrm{H}$. Much ado about something: The weight of evidence for PCB effects on neuropsychological function. Psychol. Schools 2004; 41: 669-679.

6. Bassil K, Vakil C, Sanborn M, Cole D, Kaur J, Kerr K. Cancer health effects of pesticides. Can. Fam. Phys. 2007; 53:1704-1711.

7. Salter S. The food-borne identity. Nat. Rev. Microbiol. 2014; 12:533-533.

8. Song $Q$, Zheng YJ, Xue Y, Sheng WG, Zhao MR. An evolutionary deep neural network for predicting morbidity of gastrointestinal infections by food contamination. Neurocomputing 2017; 226: 16-22. 
9. Vogt R, Bennett D, Cassady D, Frost J, Ritz B, HertzPicciotto I. Cancer and non-cancer health effects from food contaminant exposures for children and adults in California: A risk assessment. Environ. Health 2012; 11:83.

10. Kher S, Jonge JD, Wentholt M, Deliza R, Andrade J, Cnossen $\mathrm{H}$ et al. 2011. Consumer perceptions of risks of chemical and microbiological contaminants associated with food chains: A cross-national study. Int. J. Consum. Stud. 37:73-83.

11. Sheikh SA, Nizamani SM, Jamali AA, Kumbhar MI. Pesticides and associated impact on human health: A case of small farmers in southern Sindh, Pakistan Journal of Pharmacy and Nutrition Sciences, Sindh Agriculture University, Tandojam-70060, Pakistan and 2 NCEAC, University of Sindh, Jamshoro. 2011; 1: 82-86.

12. Turkdogan MK, Kilicel F, Kara K, Tuncer I, Uygan I. Heavy metals in soil, vegetables and fruit in the endemic upper gastrointestinal cancer region of Turkey. Environmental Toxicology and Pharmacology 2003; 13 (3): 175-179.

13. Akan JC, Abdulrahman FI, Ogugbuaja VO, Ayodele JT. Heavy metals and anion levels in some samples of vegetable grown within the vicinity of Challawa industrial area, Kano State, Nigeria. American Journal of Applied Sciences 2009; 6: 124-133.

14. Recio-Vega R, Ocampo G, BorjaAburto VH, MoranMartinez J, Cebrian ME. Organophosphorus pesticide exposure decrease sperm quality: Association between sperm parameters and urinary pesticide levels. J. App. Toxicol. 2008; 28:674-680.

15. Berrada H, Fernandez M, Ruiz MJ, Molto JC, Manes J, Font $\mathrm{G}$. Surveillance of pesticide residues in fruits from Valencia during twenty months (2004/2005) Food Contam. 2010; 21:36-44.

16. Gilden RC, Huffling K, Sattler B. Pesticides and health risks. J. Obs. Gyne. Neo. Nursing 2010; 39: 103 - 110.

17. Chiu YH, Afeiche MC, Gaskins AJ, William PL, Petrozza JC, Tanrikut C, Hauser R, Chavarro JE. Fruit and Vegetable intake and their pesticide residues in relation to semen quality among men from fertility clinic. Human. Reprod 2015; 0(0): 1-10.

18. Alexander J, Bedford D, Cockburn A, Cravedi JP, Dogliotti E, Domenico AD et al. Nitrate in vegetables scientific opinion of the panel on contaminants in the food chain. Journal of European Food Safety Authority 2008; 689: 1-79.
19. Tahir S, Anwar T, Ahmed I, Aziz S, Ashiq M, Ahad K. Determination of pesticide residues in fruits and vegetables in Islamabad Market. J. Environment. Biol. 2001; 22(1): 71-74.

20. Department of Health. Malathion and mosquito control. 2009. https://www.health.ny.gov/publications/2740/.

21. Pimentel D. Environmental and economic costs of the application of pesticides primarily in the United States'. Environ. Dev. Sustain 2005; 7:229-252.

22. Talib U. Role of agricultural extension 'Hub programmes in the dissemination of improved agricultural technologies among farmers in Tehsil Faisalabad. (unpublished masters thesis) Inst. of Agricultural Extension, University of Agri., Faisalabad. 2012.

23. CDC. Surveillance for foodborne disease outbreaks. United States, 2009-2010. Ann. Emerg. Med. 2013; 62:91-93.

24. Peralta VJ, Lopez M, Narayan M, Saupe G, GardeaTorresdey J. The biochemistry of environmental heavy metal uptake by plants: implications for the food chain. Int. J. Biochem. Cell Biol. 2009; 41:16651677.

25. Centre for Ecogenetics and Environmental Health. Fast facts about health risks of pesticides in food. 2013. https://depts.washington.edu/ceeh/downloads / FF_Pesticides.pdf.

26. Wesseling C, Mc-Connell R, Partanen T, Hogstedt C. Agricultural pesticide use in developing countries: Health effects and research needs. International Journal of Health Services 1997; 27(2): 273- 308.

27. Ngowi AVF, Mbise TJ, ljani ASM, London L, Ajayi OC. Pesticides use by smallholder farmers in vegetable production in Northern Tanzania. Crop Protection 2007; 26(11): 1617-24.

28. Mathews GA. Attitudes and behaviors regarding use of crop protection products: A survey of more than 8500 smallholders in 26 countries. Crop Protection 2008; 27: 834-46.

29. Aghilinejad $M$, Farshad $A$, Naghavi $M$, Haghani $H$. Assessment of the relationship between pesticide and their effects on farmer health in various state. Iran Occupational Health 2006; 3(1): 81-85.

30. Aghilinejad M, Mohammadi S, Farshad A. Effect of pesticides on farmers' health. Pejouhesh 2007; 31 (4): 327-331. 


\begin{tabular}{|c|l|l|}
\hline \multicolumn{3}{|c}{ AUTHORSHIP AND CONTRIBUTION DECLARATION } \\
\hline Sr. \# & Author(s) Full Name & \multicolumn{1}{c|}{ Contribution to the paper } \\
\hline 1 & Aisha Rani & $\begin{array}{l}\text { Study designed, Manuscript } \\
\text { writing \& statistical analysis. } \\
\text { Did review and approval for } \\
\text { manuscript. } \\
\text { Data collection and presentation } \\
\text { and securing funds. } \\
\text { Review of paper and } \\
\text { recommandation. } \\
\text { Helped in scientific and technical } \\
\text { writing. }\end{array}$ \\
\hline 3 & Aqeela Saghir & Sohaib Usman \\
\hline 5
\end{tabular}

